\title{
A Categorization Strategy for Objects Metaphors in Ekegusii Pop Songs
}

\author{
Victor Ondara Ntabo
}

School of Education and Social Sciences- Department of Languages- Karatina University- Kenya ntabovictor@gmail.com

\begin{abstract}
The principle of Great Chain of Being Metaphor (GCBM) is normally resourceful in the analysis of metaphors. This is because the GCBM assigns a place for any phenomenon in the universe in a strict hierarchical system thus helping in understanding one thing based on another. For example, the objects chain is the second last level which is very useful in conceptualizing objects metaphors in society. Composers of Ekegusii pop songs (EPS) employ objects metaphors which refer to concreteness and abstractness to communicate their message in a subjective manner. However, the GCBM does not effectively account for concreteness and abstractness in objects metaphor analysis. The paper, therefore, devises a categorization strategy to aid in the analysis of the metaphors in EPS. Using a qualitative research design, the study identifies, classifies and interprets the metaphors in the selected EPS using the Conceptual Metaphor Theory (CMT) and the Metaphor Identification Procedure Vrije Universiteit (MIPVU). Obwanchani (Love) EPS by Ontiri Bikundo was purposively sampled for the study based on its richness in metaphors and popularity in FM stations in Kenya. The research found that the objects metaphors are source domains in the construction of metaphors related to human beings in EPS. The paper concludes that metaphors are crucial ways of communication and should be analyzed using a Cognitive Linguistics approach. The study recommends that language researchers should adopt a categorization strategy to effectively analyze the objects metaphors.
\end{abstract}

Keywords: Objects metaphors, EPS, MIPVU, GCBM, Cognitive Linguistics

\section{Introduction}

The principle of Great Chain of Being metaphor (GCBM) is useful in categorizing various things in society into different levels to help in their comprehension. The GCBM is used as a theoretical framework in mapping the attributes of different categories of the chain in order to understand one chain in terms of another (Lakoff \& Turner, 1989). The major premise of the GCBM is that all things in the universe have their places in a divinely planned hierarchical order which is considered to be a vertical chain where different entity types occupy their corresponding places on the basis of their properties and behaviour (Kövecses,2002; Ntabo, Gathigia \& Nyarigoti, 2018). According to Kövecses (2002), the top most level is occupied by "GOD, then UNIVERSE, SOCIETY, HUMAN BEINGS, ANIMALS, PLANTS, OBJECTS and PHYSICAL THINGS respectively. Each of the chains contains specific characteristics which, however, can be metaphorically contrasted to help in comprehending other levels (Krzeszowski,1997). The GCBM is reported to be a tool of great scope which allows human beings to understand the general human behaviours in terms of well understood non-human characteristics (Lakoff \& Turner, 1989; Ntabo, Gathigia \& Nyarigoti, 2018).However, the GCBM does not effectively account for the objects metaphors which refer to abstractness and concreteness in the source domains. The omission prompts this study to devise a categorization strategy to help reveal the meaning of the objects metaphors in Ekegusii pop songs (EPS). The proponents of the GCBM are the ancient philosophers like Plato and Aristotle. Nisbet (1982) posits that the ancient philosophers founded the GCBM to help understand different kinds of things in terms of others in society. Although the GCBM is very useful in 
interpreting metaphors, this study is significant in unveiling a comprehensive categorization method of the objects metaphors which allude to abstractness and concreteness in the source domains in EPS.

The objects chain is the second last level in the Great Chain of Being metaphor (GCBM). The objects metaphors identified in the late Ontiri Bikundo's EPS Obwanchani (Love) highlight concreteness and abstractness in the source domains. These concepts of objects metaphors are not effectively accounted for by the GCBM. The study takes into consideration Chiape and Kennedy's (2001) proposition that a categorization strategy should be devised to assist in comprehending the objects metaphors which refer to abstractness and concreteness in the source domains. Furthermore, metaphor comprehension, as pointed out by Ntabo, Gathigia and Nyarigoti (2018), also requires a combination of comparative categorization and evaluative thinking to aid in meaning construction. López (2009) also notes that the process of contrasting a human being with an object elicits feelings of love and hatred depending on the object employed. Therefore, the present study classified the objects metaphors in EPS into two categories to aid in their comprehension. The first is the concrete objects metaphors (concreteness) and the second is the abstract objects metaphors (abstractness).

Cognitive Linguistics (CL) was used as a framework to reveal the meaning of the categorized objects metaphors in EPS. CL treats metaphor as a central issue in language analysis (Kieltyka \& Kleparski, 2005). Kövecses and Benczes (2010) also posit that CL investigates the relationship between cognition, language and culture. Meaning, therefore, is a product of social physical experiences, language and the mind. Fauconnier and Turner (2002) argue that CL is a branch of linguistics that provides that meaning is the product of the general cognitive systems that human beings use to conceptualize all aspects of reality. According to Fillmore (1975), CL was originally started in the early 1970s out of dissatisfaction with formal approaches to language and linguistics like semantics and pragmatics which were dominant at the time. Palinkas (2006), therefore, developed a framework for explaining phenomena like analogy, metaphor, metonymy and counterfactual reasoning which are not accounted for by the formal linguistics approaches.

Metaphor which is the scope of this study is primarily a conceptual phenomenon used to comprehend one thing in terms of another (Aradi, 2017; Croft \& Cruse, 2004). Etymologically, the word "metaphor" comes from the two Latin roots: "meta" which means "over," or "across" and "pherein" which means "to transfer" or to "carry beyond" (Gathigia, 2014; Glucksberg, 2001, p. 3; Ntabo, Gathigia \& Nyarigoti, 2018). Metaphor, hence, enables people to understand human thought. Kövecses (2002) also points out that metaphor is vital in revealing human thought and reasoning. This means that metaphor creates human beings' psychological, cultural and social reality. The objects metaphors which form the scope of the present study are those which refer to lifeless things in society. They fall in the second last chain of the principle of Great Chain of Being metaphor. The motivation for a study on metaphor is because, metaphor, as propounded by Lakoff and Turner (1989), is powerful as it makes it possible for people to understand human qualities based on the characteristics of other levels in the GCBM.

The data for this study was selected from Ekegusii pop songs (EPS). Ntabo, Gathigia and Nyarigoti (2018) note that the EPS appeal to a mass audience because they are hilarious, have a danceable rhythm and have melodies which are repetitive. Besides, pop music is a fundamental reference for the construction and expression of who human beings are (McDonald, Hargreaves \& Miell, 2002). Pop music is much more than an object of entertainment (De Nora, 2001; Sloboda \& O'Neill, 2001) which, therefore, requires to be analyzed to reveal the message of the composers. Bicknell (2002) posits that the meaning of pop songs is normally traced to a conscious communicative effort of the composers. Since the meaning of pop music is as varied as there are composers, it is, therefore, necessary to interpret the metaphors in EPS to objectively disclose the message of the composers.

Scruton (2005) also notes that pop songs employ metaphors to convey the composers' message subjectively. Although the audience of EPS enjoys listening to the music, the meaning of the metaphors may be elusive (Ntabo, Gathigia \& Nyarigoti). This study, thus, supports Dibben and 
Windsor's (2001) proposition that the meaning of pop music should be analyzed to reveal its true message. The need to carry out this study was also motivated by Middleton's (2000) argument that, although pop music is almost omnipresent and everywhere in the modern society, the study of pop music is still in its infancy. This is because, as noted by Frith (1988), some critics consider pop music banal and their wordings, imagery and emotions feeble. However, the audiences of pop songs find them so pleasurable and the mass audience should be helped to interpret the metaphors used to understand the message of the composers.

The Ekegusii pop composers and singers employ metaphorical language and witticism to convey messages on the concepts of love and marriage relationships (Ntabo, Gathigia \& Nyarigoti, 2018). For example, Ontiri Bikundo composed the EPS Obwanchani (Love), which has gained acclaim in Kenya because of its metaphorical language. Bikundo uses a fictitious male character, Bikundo and a female one, Kwamboka and sings about their romantic relationship. In the song, Bikundo succeeds in exposing an envious society that lacks appreciation for successful marriages.

Ekegusii is a Bantu language which is spoken in the western part of Kenya (Nurse \& Phillippson, 1980). Basweti et al (2015) places the homogenous speaking areas of Ekegusii at the present Nyamira and Kisii Counties in Kenya. Guthrie (1971) classifies Ekegusii as a central Bantu language. The 2009 Population and Housing Census approximates Ekegusii speakers at 2.2 million (Kenya National Bureau of Statistics, 2010). Bosire (1993) posits that Ekegusii has two dialects which are Ekerogoro (Northern) and Ekemaate (Southern). The two dialects are also commonly referred to as Rogoro and Maate respectively. According to Cammenga (2002), the Rogoro dialect is considered the standard variety because it is used in written works for example in grammar books to teach Ekegusii to primary school pupils in grade 1-3 and in Ekegusii Bible. Ntabo, Gathigia and Nyarigoti (2018) note that the Rogoro and the Maate dialects differ in the aspects of speech sound, vocabulary and sentence structure but the dialects have not presented variations in meaning.

\section{Theoretical Framework}

The study employed Lakoff and Johnson's (1980) the Conceptual Metaphor Theory (CMT) to analyze the objects metaphors in EPS. Aradi (2017) notes that the CMT is a dynamically developing branch of Cognitive Linguistics which was proposed by Lakoff and Johnson in their seminal paper titled Metaphors We Live By in 1980. Kieltyka and Kleparski (2005) posit that the CMT views metaphor as conceptual and, therefore, cognitive instead of a purely linguistic phenomenon. According to Kövecses and Benczes (2010), the CMT presupposes that human thinking is in the form of propositions and image representations are metaphorical. This suggests that the conceptual system of the brain is made of concrete and abstract concepts. In the CMT, the brain maps the concrete concepts which are the source domains to the abstract concepts which constitute the abstract domains to help in meaning formation (Aradi, 2017). Therefore, the brain uses the concrete or physical things to comprehend the abstract ones. In the CMT, the commonly used notation is a capitalized mnemonic with the target domain stated first and linked to the source domain via the "copula" or "as" (Gathigia, 2014; Lakoff \& Johnson, 1980; Ntabo, Gathigia \& Nyarigoti, 2018). For example, the "TARGET DOMAIN IS /AS SOURCE DOMAIN" (Ntabo, Gathigia, Nyarigoti, 2018). The provisions of the CMT are, therefore, relevant in the analysis of the objects metaphors in the EPS Obwanchani (Love) by the late Ontiri Bikundo.

\section{Methodology}

This study used a qualitative research approach. A qualitative research approach is an exploratory method used to explain how things are by informing the reader about phenomena as experienced by participants and interpreted in relevant contexts (Bryman, 2006). In particular, the content analysis which is described as a research method which examines words or phrases within a 
wide range of texts (Edman, 2010; Ntabo, 2018) was specifically used to evaluate the objects metaphors in Bikundo's EPS Obwanchani (Love). The choice of content analysis was considered relevant because, as noted by Patton (2002), it goes beyond the practice of counting words or extracting objective content from texts to evaluating meanings, themes and patterns that may be highlighted in texts. The Ekegusii pop song Obwanchani (Love) by Ontiri Bikundo was purposively sampled for study based on its richness in metaphors and popularity in Kenyan FM stations. The selected EPS was transcribed and translated into English by four native Ekegusii annotators. The annotators also helped in identifying 34 metaphors from the selected EPS using the criteria adapted from Steen et al's (2010) the Metaphor Identification Procedure Vrije Universitet (MIPVU). For example, the annotators identified words as metaphors if such words are indirectly used in such a manner that their use may be explained by some form of cross domain mapping from a more basic meaning of the words as provided by Steen et al (2010). To ensure precision, an inter rater reliability measure was used in the identification of the metaphors. The study employed a provision by Cameron (2003) that a word which attains at least 0.75 in the inter-rater reliability measure qualifies to be considered a metaphor. Each annotator, hence, allotted 0.25 to the word considered a metaphor. An agreement by three annotators was sufficient to categorize a word as a metaphor. The inter rater reliability measure has also been effectively used by Gathigia (2014) and Ntabo, Gathigia and Nyarigoti (2018). The principle of Great Chain of Being metaphor (GCBM) was then utilized to classify the 34 metaphors in the EPS into the conceptual domains of: HUMAN BEING, ANIMAL, PLANT and OBJECTS. The paper then focused on the objects metaphors with an aim of devising a categorization strategy to aid in their analysis. The metaphors were presented in tables and evaluated for metaphor meaning by the Conceptual Metaphor Theory.

\section{Data Analysis and Interpretation}

The study notes that the objects metaphors identified in Ekegusii pop songs (EPS) highlight concreteness and abstractness in the source domains. The tenets of the principle of Great Chain Being metaphor (GCBM) do not give provisions for abstractness. According to Chiape and Kennedy (2001), a classification method should be devised to comprehend the objects metaphors if they refer to concreteness and abstractness. Objects metaphors also require to be categorized to ensure effective evaluation (Gentner \& Bowdle, 2008; Gibbs, 2011). This study, therefore, classified the objects metaphors in the selected EPS into two categories to help in meaning construction. The first is the concrete objects metaphors (concreteness) and the second is the abstract objects metaphors (abstractness). The metaphors are presented in Tables 4.1 and 4.2 below and evaluated for meaning using the Conceptual Metaphor Theory (CMT) within the Cognitive Linguistics framework.

\subsubsection{Concrete Objects Metaphors (Concreteness)}

Crutch (2006) defines concreteness as the degree to which something may be perceived using the human senses. Concrete objects, therefore, express qualities or characteristics which are specific and tangible. Concrete objects are also relational in nature since they refer to objects which people can easily relate to (Crutch, 2006; Crutch \& Warrington, 2005). This suggests that it is easy to comprehend concrete objects metaphors because they draw comparison with things that we can feel and socialize with. Table 4.1 below presents the concrete objects metaphors in the EPS Obwanchani (Love).

Table 4. 1: Concrete Objects Metaphors in the EPS Obwanchani (Love)

\begin{tabular}{|l|l|l|}
\hline NO & Ekegusii & Gloss \\
\hline 1 & Omonto n' egete & A human being is a stick \\
\hline 2 & Omonti n' nyomba & A human being is a house \\
\hline 3 & Omonto n' egari & A human being is a vehicle \\
\hline 4 & Omonto n' e Toyota & A human being is a Toyota \\
\hline
\end{tabular}


Metaphor (1) above is employed to express the envy and malice labeled on happy couples in Bikundo's society. A stick, for example, is a tiny branch of a tree whose thin shape is normally caused by drying up. The egete (a stick) metaphor (1) below, therefore, insinuates a human being whose body weight has decreased over time. Thus:

\section{(1) OMONTO N' EGETE - 'A HUMAN BEING IS A STICK'.}

In metaphor (1) above, Bikundo laments that his wife, Kwamboka who was big in body size a few months before is presently comparable with egete (a stick). Rapid reduction of a person's weight and size cannot only be attributed to lack of sufficient food but also depression and general sickness (Barrett, 2001). In (1) above, omonto (a human being) is the target domain (TD) while egete (a stick) is the source domain (SD) according to the CMT. The conceptual mapping between the SD corresponding to the TD in this context is physical appearance corresponding to perception. Kwamboka, thus, is a slender, slim and an emaciated human being whose body weight has apparently drastically decreased due to depression. Bikundo apportions blame to his critics for Kwamboka's reduced body weight. He sings that his critics who have failed to accommodate his happy marriage in their society have succeeded to maliciously incite Kwamboka (his wife) against him and thus causing her unnecessary depression. Bikundo, therefore, suggests that his wife, Kwamboka has fallen into his critics' traps who apparently intend to severe their matrimonial relationship.

Jones (2006) observes that a house is one of the components of a home where affection and love are shared. Lovers in romantic love relationships are usually deeply concerned about the welfare of their companions (Kövecses, 1988). Therefore, the ability to provide a decent shelter can draw the emotional involvement of the lover in a romantic love relationship. Therefore:

(2) OMONTO N' ENYOMBA - 'A HUMAN BEING IS A HOUSE'.

In metaphor (2) above, Bikundo sings that he is not enyomba (a house) which suggests that a human being is a house in society. A house is a building which functions as a home where human beings dwell. It is also one of the basic human needs where family members acquire protection from the cold at night and shelter during the scorching midday sun. Kandula (2012) posits that human beings who own houses enjoy high social status is society since being able to possess one is an indication that a person is able to provide basic needs for family members. In metaphors (2) above, omonto (a human being) is the target domain (TD) while enyomba (a house) is the source domain (SD) as per the CMT. Therefore, one of the conceptual mappings between the SD corresponding to the TD is physical appearance corresponding to protection and affection. Example (2) above, thus, suggests that Bikundo is impoverished but beseeches his wife, Kwamboka to uphold their love relationship despite Bikundo' inability to guarantee her a house. In his song, Bikundo is optimistic of acquiring a family house once his fortunes change to provide protection and affection for his wife.

Possession of egari (a vehicle) is essential because peoples' movement from one place to another is made easy. People who own vehicles in third worlds like many developing countries in Africa are considered to be in a prestigious social class (Jones, 2006). The egari (vehicle) metaphors (3) and (4) below are employed in the EPS Obwanchani (Love) to present Bikundo's fears of losing his beloved wife, Kwamboka because he does not possess a vehicle. Thus:

\section{(3) OMONTO $N$ ' EGARI -'A HUMAN BEING IS A VEHICLE',}

\section{(4) OMONTO $N$ ' E TOYOTA -'A HUMAN BEING IS A TOYOTA'.}

In metaphors (3) and (4) above, a human being is conceptualized as a vehicle. Omonto (a human being) is the TD while egari (a vehicle) is the SD. The conceptual mapping between the SD corresponding to the TD in this context is physical appearance corresponding to perception. Metaphor (3), therefore, insinuates that Bikundo is poverty stricken which causes him to have reservation about his wife, Kwamboka's commitment in their marriage, as he sings that he is not egari (a vehicle). Bikundo is cognizant that being in possession of a vehicle is necessary which prompts him to expresses optimism in metaphor (4) that one day he will be a Toyota. Kandula (2012) also posits that being in possession of a vehicle is associated with high social status especially 
in a society with limited earnings. Kandula further postulates that vehicles are crucial in households to aid easy movements. Toyota is a brand name for Japanese automobiles manufacturing firm referred to as Toyota (Fujio, 2014). Fujio further notes that Toyota is the world's first vehicle manufacturer to assemble more than ten million vehicles annually. Metaphor (4) above, therefore, implies that Toyota cars are famous and prestigious prompting Bikundo to forecast of being one. Bikundo is, thus, convinced that obwanchani (love) can thrive if the couples live in optimism of filling the gap of what eludes them today. Bikundo also depicts a strong love for Kwamboka which authenticates Barcelona's (1995) argument that lovers cannot do without one another.

\subsubsection{Abstract Objects Metaphors (Abstractness)}

Abstractness is the extent to which something is not realized by the human senses (Crutch, 2006). This means that an abstract object is not specific or tangible. Abstract objects have been found to be more relational or schematic and they normally evoke other abstract concepts for instance feelings and reflections (Crutch, 2006; Crutch \& Warrington, 2005). Abstract things also require a high level of analytical thinking to process (Chiape \& Kennedy, 2001). This study analyzed the abstract objects metaphors in the selected EPS to reveal meaning. Table 4.2 below presents the objects metaphors in Obwanchani (Love) EPS by the late Ontiri Bikundo.

Table 4. 2: Abstract Objects Metaphors in the EPS Obwanchani (Love).

\begin{tabular}{|l|l|l|}
\hline NO & Ekegusii & Gloss \\
\hline 5 & Omonto n' ekeng'ong'ino & A human being is ugliness \\
\hline 6 & Omonto n' obomwamu & A human being is blackness \\
\hline 7 & Omonto n' oborabu & A human being is light \\
\hline 8 & Omonto n' obobariri & A human being is redness \\
\hline 9 & Omonto n' ekelele & A human being is noise \\
\hline
\end{tabular}

The ugliness metaphor (5) below reveals human being's subjective judgement about other people's physical appearance. Rhodes (2010) argues that human beings normally associate with what is considered attractive in society. Bikundo expresses admiration for his wife, Kwamboka in the EPS although other people perceive Kwamboka as ekeng'ong'ino (ugliness). Thus:

\section{(5) OMONTO N' EKENG'ONG'INO - 'A HUMAN BEING IS UGLINESS'.}

Bikundo sings that his critics conceptualize his wife, Kwamboka as ekeng'ong'ino (ugliness) as shown in metaphor (5) above. Bikundo suggests that they do this to incite him to desert his beloved wife. Therefore, in (5) above, Omonto (a human being) is the TD while ekeng'ong'ino (ugliness) is the SD. The conceptual mapping between the SD corresponding to the TD in this context is physical appearance corresponding to perception. Rhodes (2010) defines ugliness as something which is unattractive or unpleasant to look at. An ugly person, thus, is one who is displeasing in appearance. Rhodes further notes that what one person considers ugliness might be perceived as beauty by another person. This is why Bikundo positively conceptualizes his wife, Kwamboka as a beautiful person unlike his critics who negatively label her as ekeng'ong'ino (ugliness). Bikundo's gentle feelings for Kwamboka authenticates the proverbial metaphor that beauty lies in the hands of the beholder.

Instantiations (6), (7) and (8) below reveal that we use language which highlight colour metaphors to help us understand what we see. (6), (7) and (8) highlight Bikundo's mastery of the use of colour images to help readers to have a glance at his mental state and infer his pain. Thus:

(6) OMONTO N' OBOMWAMU - “A HUMAN BEING IS BLACKNESS”,

(7) OMONTO N' OBORABU - “A HUMAN BEING IS LIGHT”,

(8) OMONTO N' OBOBARIRI - “A HUMAN BEING IS REDNESS”.

Bikundo laments that his wife, Kwamboka whom he equates with obomwamu (blackness) was once comparable with oborabu (light) and obobariri (redness). Bikundo, in the EPS Obwanchani (Love) reproaches abagengi (malicious people) for Kwamboka's obomwamu (blackness) state. Colour evokes not only cultural ideas but also psychological associations which symbolize issues, 
attitudes and reflections (Malamed, 2009). For example, blackness which is a state of being black is a symbol of despair and depression. The obomwamu (blackness) metaphor reveals Bikundo's pain as Kwamboka is in a state of despair in their marriage relationship. Since context plays a part in colour symbolism (Malamed, 2009), the obobariri (redness) and oborabu (light) metaphors represent Bikundo's nostalgic feelings of joy, passion, and love the couple once enjoyed before abagengi (malicious people) incited Kwamboka against her husband, Bikundo. Metaphors (7) and (8) are, therefore, used to positively conceptualize Kwamboka whom Bikundo describes using the warm colours of obobariri (redness) and oborabu (light). This reveals the argument that human eyes, as pointed out by Malamed (2009), are attracted to bright colours since viewers derive meaning from what stands out. Metaphor (6) is used to negatively conceptualize a human being. Bikundo describes Kwamboka as obomwamu (blackness) which is a cool colour. According to Melamed (2009), cool colours normally recede. Bikundo, therefore, is in a deep mental pain which is motivated by Kwamboka's apparent depression.

The metaphor of noise as shown in (9) below is also used to conceptualize human beings. Since noise is usually distractive, a human being who meddles in other people's private matters is negatively equated with noise. Therefore:

\section{(9) OMONTO N’ KELELE -“A HUMAN BEING IS NOISE".}

Bikundo, in the EPS Obwanchani (love) sings that any person who pokes his nose in other people's personal matters is tantamount to noise. Scales and Snielder (1998) describe noise as unwanted sound judged to be unpleasant, loud or disruptive to the ear. Bikundo, thus, insinuates that his critics who have worked tirelessly to disrupt his matrimony by inciting his wife against him are the noises. Since noise hinders the realization of the expected signal (Scales \& Snielder, 1998), noisy persons, thus, will hardly realize their objective in life. Metaphor (9) above, therefore, is given as a piece of advice to members of Bikundo's society to desist from interfering with married people's private lives.

\section{Conclusions and Recommendations}

In line with the findings and discussion above, this study concludes in the following ways: first, categorizing the objects metaphors into concreteness and abstractness was very useful in evaluating the objects metaphors in Obwanchani (Love) EPS by Ontiri Bikundo for meaning; second, metaphors are essential ways of passing message and should be evaluated using a Cognitive Linguistics paradigm; third, the Conceptual Metaphor Theory was resourceful in unearthing the message of the composer of EPS regarding the objects metaphors in Bikundo's Obwanchani (Love) EPS; fourth, language is both embodied and situated in a specific environment, making it possible for the meaning of some of the metaphors used to elude the audience of EPS and ; lastly, the Metaphor Identification Procedure Vrije Universiteit is an effective method of identifying metaphors from songs.

The paper, therefore, suggests that for a better comprehension of objects metaphors in songs, it is important to devise a categorization strategy to aid in the understanding of the abstract and concepts used in the metaphors. In addition, the paper recommends the use of the Conceptual Metaphor Theory (CMT) and Steen et al's (2010) Metaphor Identification Procedure Vrije Universiteit to help in identifying and analyzing the metaphors used in texts. 


\section{Refernces:}

[1] Aradi. E. C., A diachronic investigation of the Great Chain of Being Metaphor in religious and political discourse of early modern and enlightenment philosophy, International Journal of Humanities and Social Science, 7(6)(2017), 214-222

[2] Barcelona. A., Metaphorical models of romantic love in Romeo and Juliet, Journal of Pragmatics, 24(6)(1995), 667-688, https://doi.org/10.1016/0378-2166(95)00007-f

[3] Barret, C.B., Does food aid stabilize food availability? Economic Development and Cultural Change, 49(2) (2001), 335-349, https://doi.org/10.1086/452505

[4] Basweti. O. E., et al., Ekegusii DP and its sentential symmetry: A minimalist inquiry, International Journal of Language and Linguistics, 2(2)(2015), 93-107.

[5] Bicknell. J., Can music convey semantic content? A Kantian approach, The Journal of Aesthetics and Art Criticism, 60(3)(2002), 253-261, https://doi.org/10.1111/1540-6245.00072

[6] Bosire. F., Dialects Rogoro and Maate, Kenya (Unpublished MA thesis), University of Nairobi, Kenya, (1993)

[7] Bryman. A., Integrating quantitative and qualitative research: how is it done?, Qualitative Research, 6(1) (2006), 97-113, https://doi.org/10.1177/1468794106058877

[8] Cammenga. J., The phonology and morphology of Ekegusii- A Bantu language of Kenya. Koln: Rudiger Koppe Verlag, (2002)

[9] Chiape. D. L., \& Kennedy. J. M., Literal bases for metaphor and simile, Metaphor and Symbol, 16(3)(2001), 249-276, https://doi.org/10.1207/s15327868ms1603\&4_7

[10] Croft. W., \& Cruse. D. A., Cognitive Linguistics. Cambridge University Press, (2004)

[11] Crutch. S. J., Qualitatively different semantic representations for abstract and concrete words : Further evidence from the semantic reading errors of deep dyslexic patients, Neurocase, 12(2) (2006), 91-97, https://doi.org/10.1080/13554790500507172

[12] Crutch. S. J., \& Warrington. E. K., Abstract and concrete concepts have structurally different representational frameworks. Brain, 128(3)(2005), 615-627, https://doi.org/10.1093/brain/awh349

[13] De Nora. T., Aesthetic agency and musical practice: New directions in the sociology of music and emotion. In J.A. Sloboda and P. Juslin (Eds.), Music and emotion: Theory and research, (2001), pp.161-180, Oxford: Oxford University Press.

[14] Dibben,N., \& Windsor. L., Constructivism in Nicholas Cook's introduction to music: Tips for a "new" psychology of music, Musicæ Scientiæ Discussion Forum, (5)2(2001), 43-50, https://doi.org/10.1177/10298649010050s207

[15] Eleanor. A. C., The impact of idealized images of female beauty of women's self concept: Who does it affect and when? (Unpublished doctoral dissertation), University of Massachusetts, USA, (2006)

[16] Fauconnier. G., \& Turner. M., The way we think: Conceptual blending and the mind's hidden complexities, New York: Basic Books, (2002)

[17] Fillmore. C., An alternative to checklist theories of meaning. In C. Gogen, H. Thompson, \& J. Wright (Eds.), Proceedings of the First Annual Meeting of the Berkeley Linguistics Society, (1975), pp. 123-131, Berkeley, U.S.A: Berkeley Linguistics Society 
[18] Frith.S., Music for pleasure. Cambridge: Polity Press, (1988)

[19] Fujio.C., Toyota way document. Taiwan: National Cheng Kung University Press, (2014)

[20] Gathigia. M. G., Metaphors of love in Gikuyu: Conceptual mappings, vital relations and image schemas (Unpublished doctoral thesis), Kenyatta University, Kenya, (2014)

[21] Gentner. D., \& Bowdle. B., Metaphor as structure-mapping. In R. W. Gibbs (Ed.), The Cambridge handbook of metaphors and thought, (2008), pp. 109-128, New York: Cambridge University Press.

[22] Gibbs.R. W., Evaluating Conceptual Metaphor Theory, Discourse Processes, 48(8)(2011), 529-562, https://doi.org/10.1080/0163853x.2011.606103

[23] Glucksberg. S., Understanding figurative language. From metaphor to idiom, Oxford: Oxford University Press, (2001)

[24] Guthrie. M., Comparative Bantu: An introduction to the Comparative Linguistics pre-history of Bantu languages. Farnborough: Gregg press, (1971)

[25] Jones. A., Violence and "othering" in colonial and post colonial Africa. Case study: Banda's Malawi, Journal of African Cultural SNtudies, 18(2)(2006), 197-213, https://doi.org/10.1080/13696810601105038

[26] Kandula. B. U., Do the causes of poverty vary by neighborhood type? (Unpublished doctoral thesis), Cleveland University, USA, (2012)

[27] Kenya National Bureau of Statistics, 2009 Kenya population and housing census: Population distribution by age, sex and administrative units, vol. 1c. Nairobi: Government Press, (2010)

[28] Kieltyka. R., \& Kleparski. G., The Scope Of English Zoosemy: The Case Of DOMESTICATED ANIMALS. Studia Anglica Resoviensia, 3(2005), 76-87.

[29] Kövecses. Z., The language of love: The semantics of passion in conversational English. Lewisburg, Pa: Bucknell University Press, (1988)

[30] Kövecses. Z., Metaphor: A practical introduction. Oxford: Oxford University Press, (2002)

[31] Kövecses. Z., Metaphor in culture: Universality and variation. New York: Cambridge University Press, (2005)

[32] Kövecses. Z., \& Benczes. R., Kognitivnyelveszet. Budapest: Akademiai-Kiado, (2010)

[33] Krikman. A., A diachronic investigation of the Great Chain of Being as the background of personificatory and depersonificatory metaphors in proverbs and elsewhere. Proceedings of the First Interdisciplinary Colloquium on Proverbs, (2007),pp. 1-24, Portugal: Hotel Vila Gale, Tavira(Agarve).

[34] Lakoff. G., \& Turner. M., More than cool reason: A field guide to poetic metaphor. Chicago: University of Chicago Press, (1989)

[35] Krzeszowski. T. P., Angels and devils in Hell: Elements of axiology in semantics. Warszawa: Wydawnic two Energeia, (1997)

[36] López. I., Of women, bitches, chickens and vixens: animal metaphors for women in English and Spanish. Cultura, Lenguaje y Representación/Culture, Language and Representation, 7(7)(2009), 77-100.

[37] Malamed. C., Gestalt you graphics: Improving instructional graphics, Graphics, Technolgy and Strategy, 2(2009), 22-30. 
[38] McDonald. R., Hargreaves. D. J., \& Miell. D., What are musical identities, and why are they important? In McDonald, R., Hargreaves, D. J., \& Miell, D.(Eds.) Musical Identities. Oxford: Oxford University Press, (2002),1-20.

[39] Nisbet. R., Prejudices: A philosophical dictionary. Cambridge, Mass: Havard University Press, (1982)

[40] Ntabo. V. O., A cognitive semantics analysis of Fulstop and Valentine Taarab songs by Khadija Kopa and Mzee Yusuf, International Journal of Psychology Research, 12(1)(2018), 61-74.

[41] Ntabo. V. O., Gathigia. M.G., \& Nyarigoti. N. M., A cognitive approach to EkeGusii pop songs, Advances in Language and Literary Studies, 9(3)(2018), 166-172, https://doi.org/10.7575/aiac.alls.v.9n.3p.166

[42] Nyakoe. G. N., Ongarora. D. O. \& Oloo. P., An analysis of the food metaphor in EkeGusii HIV and AIDS discourse, International Journal of Academic Research in Business and Social Sciences, 4(1)(2014), 221 -228.

[43] Nyakundi. A. O., The translation of figurative language in the book of Proverbs in EkeGusii Bible (Unpublished MA thesis), Kenyatta University, Kenya, (2010)

[44] Palinkas. I., The development of the senses argumentum, Kossuth Egyetemi Kiado, Derecen, 2(2006), 191197.

[45] Patton. M., Qualitative evaluation and research methods. Newbury Park: Sage Publications, (2002)

[46] Rhodes. L. K., An apparent ugliness: Fashion and dressing poor (Unpublished MA thesis), RMIT Unuversity, Australia, (2010)

[47] Scales. A. J. \& Snielder. R., What is noise? Geophysics, 63(4)(1998), 1122-1124.

[48] Scruton. R., Philosophy: Principles and problems. London: The University of Chicago Press, (2005)

[49] Sloboda. J., \& O’Neill. S., Emotions in everyday listening to music. In Sloboda and Juslin (Eds.) Music and emotion: Theory and research, Oxford: Oxford University Press, (2001),pp. 415-429.

[50] Steen. G., et al., A method for linguistic metaphor identification. Amsterdam: John Benjamins Publishing Company, (2010)

[51] Sullivan. S., Pop music. Encyclopedia of great popular song recording, 2(2013), 101-103. 